\title{
Realidad humana y religación en Zubiri y su recepción en Ellacuría ${ }^{1}$
}

\author{
Hugo Gudiel, \\ Centro de Reflexión Teológica, \\ San Salvador.
}

\section{Introducción}

La realidad humana y la religación tienen una intrínseca relación en el pensamiento antropológico de Xavier Zubiri. De hecho, el filósofo trató unitariamente ambos temas en su obra póstuma El hombre y Dios, antes de abordar la cuestión de la realidad divina. Ya en 1966 Ignacio Ellacuría captó aquella intrínseca relación, al detenerse en la exposición de la religación como actitud radical del hombre. Nuestro interés en este trabajo consiste en presentar, por una parte, la concepción madura de Zubiri sobre el ser humano y la religación. Por otra parte, busca poner de manifiesto la recepción temprana de Ellacuría sobre la religación como actitud radical del hombre.

Así, pretendemos responder a las siguientes cuestiones: ¿qué es el hombre y qué papel juega la religación en la constitución de su ser relativamente absoluto? ¿Cómo se va constituyendo la realidad del ser humano? ¿Por qué la religación es la actitud radical del hombre? Nuestro interés es mostrar que la religación es esencial en la constitución de la realidad del hombre.

El artículo tiene dos secciones. En la primera concentramos nuestra atención en la primera parte de la obra de Zubiri: El hombre y Dios. Se trata de una primera parte que está, según Ellacuría, "conclusa y revisada" por el propio Zubiri, y que además pertenece a la "última época" del filósofo ${ }^{2}$. Cabe destacar que en

1. En este contexto puede verse A. González, "Ignacio Ellacuría, filósofo", en P. J. Beltrán de Heredia (ed.), Vascos universales del siglo XX. Juan Larea e Ignacio Ellacuría, Madrid, 2005. Reproducido con el título "Ellacuría, discípulo de Zubiri”, en la revista Philosofica 28 (2005), pp. 161-174.

2. I. Ellacuría, "Presentación", en HD, pp. i y ss. [El significado de la sigla acá utilizada y de las que siguen puede encontrarse al final del artículo. Nota de los editores.] 
esa primera parte de El hombre y Dios, Zubiri ofrece "una síntesis muy elaborada de su antropología incorporando su pensamiento más maduro"3. En 1964 Ellacuría afirma que "lo primero que a modo de introducción debe decirse sobre esta antropología es que se trata de una obra filosófica, condicionada por la idea que de filosofía tiene Zubiri y también por lo que es su misma filosofía. Su antropología está así al fin de su pensamiento, no al comienzo"4.

En la segunda sección presentamos la recepción temprana de Ellacuría sobre la religación. Aquí exponemos las ideas básicas del trabajo de Ellacuría "La religación, actitud radical del hombre"s.

De esta manera, la primera parte del trabajo, desde la perspectiva del Zubiri de la última época, ofrece el marco teórico maduro para encuadrar e interpretar en modo adecuado lo que presentamos de Ellacuría en la segunda sección de nuestro artículo.

\section{Realidad humana y religación en X. Zubiri ${ }^{6}$}

\subsection{La realidad humana ${ }^{7}$}

\subsubsection{El sistema de la sustantividad humana ${ }^{8}$}

El hombre es una sustantividad compuesta por tres grupos de notas. El primero está formado por aquellas notas gracias a las cuales él vive: es la vida. El

3. J. L. Cabria Ortega, Relación Filosofía-Teología en el pensamiento de Xavier Zubiri, p. 274.

4. I. Ellacuría, “Antropología de Xavier Zubiri”, en Escritos filosóficos II, San Salvador, 1999 , p. 72.

5. I. Ellacuría, "La religación, actitud radical del hombre", en Escritos teológicos I, San Salvador, 2000, pp. 39-105.

6. Véanse también D. Ferrer, Razón y religación. Una aproximación radical a la filosofía de Zubiri, Madrid, 2008; D. Gracia Guillén, Voluntad de verdad. Para leer a Zubiri, Barcelona, 1986, pp. 210-236; H. C. Gudiel García, La fe según Xavier Zubiri. Una aproximación al tema desde la perspectiva del problema teologal del hombre, Roma, 2006, pp. 63-88; y J. Sáez Cruz, La accesibilidad de Dios. Su mundanidad y transcendencia en X. Zubiri, Salamanca, 1995, concretamente, las pp. 205-226.

7. En 1986 Ellacuría constata que "la preocupación y consiguiente ocupación de Zubiri sobre el problema filosófico del hombre es casi constante e ininterrumpida a lo largo de sus más de sesenta años de producción teórica. En algún sentido puede decirse que todo lo escrito y hablado por él tiene que ver con el hombre, sea porque lo humano se convierte en objeto inmediato de su reflexión sea porque lo humano queda iluminado al menos mediatamente por ella [...] Desde su primer escrito sobre la religación (1935) hasta los dos primeros capítulos de El hombre y Dios (1982-1983) y lo último escrito por él sobre la génesis de la realidad humana, han sido muchos los trabajos de toda índole [...] dedicados al problema del hombre" (I. Ellacuría, "Presentación", en SH, pp ix-xxiii).

8. En este punto puede verse también I. Ellacuría, "Introducción crítica a la antropología filosófica de Zubiri”, en Realitas II, pp. 110-117. 
ser vivo tiene una cierta "independencia" y "control" sobre el medio (HD 30). Pero lo radical de la vida consiste en que el ser vivo es un "sí mismo", un autós. Por tanto, "vivir es autoposeerse, y todo el decurso vital es el modo de autoposeerse" (HD 31).

Además, el hombre es un viviente animal en el que se ha desgajado la función de sentir. Es lo propio del animal, sentir es tener impresiones. Toda impresión tiene el momento de "afección" al viviente y el de "remisión" a algo otro (HD 31). En virtud del primer momento, la impresión tiene un contenido determinado, y gracias al segundo el contenido es alteridad. La unidad de ambos momentos es la "impresión". Efectivamente, la "afección nos hace sentir impresivamente lo otro". Cada sentido tiene su forma concreta de alteridad, pero en definitiva todas ellas se inscriben en la forma radical de alteridad llamada formalidad (HD 32).

Finalmente, el hombre siente realmente el estímulo, por eso es formalidad de realidad (HD 34). Esta formalidad es un acto unitario: es intelección sentiente. La inteligencia siente la realidad (HD 35). Inteligir y sentir constituyen dos momentos de un acto único y estructural: "inteligencia sentiente". "Es la unidad de la aprehensión misma de la realidad como formalidad de las cosas" (HD 36). Por tanto, realidad es la formalidad del "de suyo" (HD 37). A esta concepción de la realidad va unida la de la inteligencia. Inteligir es la "mera actualización de lo real como real en la inteligencia sentiente" (HD 39). Es la unidad de inteligencia y realidad.

En definitiva, el hombre vive, siente e intelige sentientemente. La unidad de tales notas es lo que constituye el "sistema de la sustantividad humana" (HD 39).

\subsubsection{Los subsistemas de la sustantividad humana}

La sustantividad humana tiene dos subsistemas: el "cuerpo" y la "psique" (HD 39).

El cuerpo es un subsistema de notas "físico-químicas" en las que se distinguen tres momentos. Por el primero, "cada nota tiene una posición funcional [...] respecto de las funciones" de las demás notas. Gracias a ello, las "notas físico-químicas constituyen como subsistema posicional" lo que aquí se llama "organismo". Además, el "de" hace de las notas "una compago de notas físicoquímicas". En virtud de ello el cuerpo es principio de solidaridad. Esto significa que cada nota influye sobre las demás, y por eso son notas "interdependientes". Pero el momento más radical del cuerpo consiste en que las "notas organizadas y solidarias expresan la actualidad del hombre en el universo". Es justo el "cuerpo como principio de actualidad en la realidad" (HD 40).

Pues bien, la unidad de organismo, solidaridad y actualidad constituye el "cuerpo" (HD 40). 
El segundo subsistema es la "psique" y ha de considerarse en el ámbito de la entera sustantividad humana. El hombre "es" una unidad "psico-orgánica" . La sustantividad humana radica en la unidad rigurosa del sistema psico-orgánico. Ambos subsistemas son indisociables. La psique es "psique-de" este organismo; y éste es "organismo-de" esta psique. Por eso, la psique es orgánica y el organismo es psíquico. Aquí se trata de rigurosa unidad "estructural" (HD 41).

Los momentos de este sistema sustantivo se codeterminan como momentos "cuya codeterminación consiste en ser cada uno 'de' todos los demás" (HD 41-42). En este "de" consiste la unidad de la sustantividad humana y su propia "mismidad" en el transcurso de toda la vida. En esta perspectiva, la actividad humana expresa esta unidad sistemática psicoorgánica. Ahí toda nota actúa como "nota-de". Es decir, su "actuación" es un momento de la "actividad-de" todas las notas (HD 42).

Pues bien, la actividad de cada nota es "actividad-de", del sistema. En efecto, "todas sus actividades constituyen una sola actividad: la actividad de la sustantividad". La actividad humana es al mismo tiempo "psico-orgánica" en todos sus actos. Es la actividad del sistema entero, por eso la actividad humana tiene carácter de "sistema". Naturalmente, en tal actividad pueden dominar unos caracteres más que otros. Sin embargo, esto no elimina el carácter unitario de la actividad del sistema sustantivo humano (HD 43).

Por tanto, puede decirse que "todo lo orgánico es psíquico", y a la inversa. La razón de ello radica en que "todo lo psíquico transcurre orgánicamente, y todo lo orgánico transcurre psíquicamente" (HD 43).

\subsubsection{La sustantividad humana es animal de realidades}

Ahora bien, ¿qué es formalmente la sustantividad humana? Ante todo, el hombre, por vivir y sentir, es similar a todo animal. En el animal, la formalidad de estimulidad constituye el ámbito de la "estimulidad en que se despliegan los diversos actos animales". Todo acto sensible tiene tres momentos: el "receptor", el "tónico" y el "efector". La "recepción lo es del estímulo", y éste modifica el tono vital del estado del animal, lo cual desencadena en él la respuesta (HD 44). Por tanto, la unidad de estimulación, afección y tendencia constituye el sentir (cfr. HD 45).

En cambio, la formalidad del hombre es formalidad de realidad. Y es ella la que "constituye el ámbito mismo en que se despliegan todos los actos humanos". En virtud de la modificación del tono vital en la realidad humana, la "afección tónica" se convierte en sentimiento. De esta manera, "sólo hay sentimiento cuando el afecto envuelve formalmente el momento de realidad" (HD 45).

9. Ibíd., pp. 114-115. 
Ahora bien, cuando la aprehensión de lo real modifica los sentimientos humanos, "lanza" al hombre a "responder". Aquí se trata del modo humano de "tender a situarse realmente de otra manera en la realidad". Para lo cual es necesario "optar". Este es el origen de la volición. Es volición real: "se quiere un modo de estar en la realidad" (HD 45).

La novedad que se pone de manifiesto en el ser humano, por tanto, consiste en que la "unidad meramente estimúlica de estimulación, afección tónica y tendencia, se torna en unidad procesual "humana". Es decir, se convierte en "proceso de realización (aprehensión de lo real, sentimiento de lo real, volición de lo real)" (HD 45).

Pero la unidad de lo sensible animal y de lo propiamente humano no se yuxtaponen, sino que la "unidad animal es un momento intrínseco y formalmente "constitutivo" de la unidad humana". Por eso, la inteligencia es sentiente, el sentimiento es afectante y la voluntad es tendente. Ahora bien, "la unidad biológica del sentir es la esencia de la animalidad". De lo cual se desprende que lo "humano en cuanto tal es en sí mismo formal y constitutivamente animal". Pues bien, el "hombre es un animal que se enfrenta con la realidad animalmente". El hombre es efectivamente animal de realidades. He aquí la esencia de la sustantividad humana; su "ámbito" es la realidad. Por tanto, desde la perspectiva de sus notas el hombre es "animal de realidades" (HD 46) ${ }^{10}$.

En definitiva, como el hombre vive, siente e intelige es un sistema sustantivo de notas psicosomáticas. Su formalidad de realidad está abierta: es animal de realidades.

Ahora bien, gracias a esas notas, la realidad humana tiene una estructura más profunda. Veámosla a continuación (cfr. HD 47).

\subsubsection{El hombre: animal personal y absoluto relativo}

En primer lugar, por ser animal de realidades, el hombre no sólo es "de suyo", sino también es "suyo". En este sentido, él tiene una realidad que le pertenece, es su propia realidad. Por tanto, la realidad humana tiene como forma de realidad la suidad, el ser "suyo". En efecto, el hombre es formalmente suyo, es suidad. La suidad es la "forma de la realidad humana en cuanto realidad" (HD 48).

La "suidad" constituye la "razón formal de la personeidad". El ser persona como forma de realidad es justo la personeidad. "La suidad es la raíz y el carácter formal de la personeidad en cuanto tal". Ahora bien, las transformaciones concretas que la personeidad va adquiriendo en el transcurso de su vida es la personalidad (HD 49). Por tanto, la personalidad es la figura en virtud de la cual

10. Sobre esta cuestión, véase también I. Ellacuría, “Antropología de Xavier Zubiri”, en Escritos filosóficos II, pp. 75-111. 
la "forma de realidad se va modelando en sus actos y en cuanto se va modelando en ellos" (HD 49-50).

Se es personeidad por tener inteligencia. La personeidad es algo constitutivo y es "siempre la misma" (HD 50). En cambio, la personalidad se va formando en el transcurso de "todo el proceso psico-orgánico desde que el embrión humano posee inteligencia, hasta el momento de la muerte". Ambos momentos lo son de una única realidad, la "personalidad es el momento de concreción de la personeidad" (HD 51).

En definitiva, desde su forma de realidad, el hombre es animal personal (HD 51).

En segundo lugar, el hombre también está implantando de forma independiente en la realidad, formando parte de ella. Recordemos que el hombre es suyo, se pertenece "frente a toda realidad". En ese sentido, su realidad tiene una independencia que consiste en "estar suelta de las cosas reales en cuanto reales". Es decir, el modo según el cual el viviente humano está implantado en la realidad es un "modo de realidad ab-soluto" (HD 51).

El modo de implantación del hombre en la realidad es ser un absoluto relati$v o$; "es absoluto porque es suyo frente a toda realidad posible". Y, a la vez, es relativo porque tal modo de implantación es un "carácter cobrado" por la persona en los actos de su vida. Esto pone de manifiesto la gravedad de todo acto humano: es la inquietud de la vida. Esta inquietud consiste en que el hombre no sabe bien el "modo concreto de ser absoluto". La inquietud es precisamente el "problematismo de lo absoluto" (HD 52). Por tanto, el modo de realidad consiste en ser absoluto relativo, cobrado en medio de la inquietud de la vida en el mundo.

En definitiva, la forma humana de realidad consiste en ser animal personal y su modo consiste en ser absoluto relativo. Pero además, lo humano es.

\subsubsection{El ser de la realidad humana}

El ser no se identifica con la realidad, pero el ser es la "actualidad de lo real en el mundo" (HD 53). Hay ser porque hay realidad, es "realidad siendo". Por esto se trata del "ser de lo sustantivo" 11 . El ser es actualidad mundanal, es ulterioridad estructural respecto de la realidad (HD 54) y es "realidad siendo" (HD 55).

En el caso del hombre, la "actualidad mundanal" de su realidad personal es el "Yo". Es el ser de la persona humana. El Yo consiste en ser un "modo de actualidad mundanal de lo relativamente absoluto". Al Yo puede llamársele "ser relativamente absoluto" (HD 56). El Yo expresa riqueza de actualización

11. Sobre esta precisión importante del Zubiri maduro, puede verse IRE, p. 222; IL, p. 352. 
$(\text { HD 57 })^{12}$. El Yo también tiene una figura determinada: la "personalidad" (HD 58).

Ahora bien, la realidad humana no solo es una realidad relativamente absoluta frente a las cosas, sino también frente a otras personas (HD 60) ${ }^{13}$. Cada persona, además, está "co-determinada" por otras personas (HD 62). Y la codeterminación de las personas se produce según la dimensión individual, social e histórica ( $c f r$. HD 63-73) ${ }^{14}$. Tales dimensiones alcanzan su plena realización en la religación ${ }^{15}$.

\subsection{Religación y realidad humana ${ }^{16}$}

Recordemos que el hombre es realidad humana. Ahora bien, ¿cómo esta realidad llega a ser hombre? El hombre es suidad. Es una realidad relativamente absoluta, es vida. La vida humana es autoposesión que se va realizando en la ejecución de sus acciones, y estas se "ejecutan porque la vida se plasma en ellas" (HD 75).

\subsubsection{El hombre y sus acciones}

El hombre como ejecutor de sus acciones es agente de ellas (HD 76). Y toda acción está ejecutada por la totalidad del sistema sustantivo humano, en el que puede haber predominio de unas notas sobre otras. Por tanto, el hombre es "agente de su vida: se posee a sí mismo por la actuación de sus potencias y facultades" (HD 77).

Ahora bien, el hombre ejecuta sus acciones en un determinado "contexto vital" que le ha sido dado. Por eso él también es actor de sus acciones: es "actor de su propia vida". En cierto modo, el ser humano es el "gran personaje de su vida" (HD 77).

Ejecutando acciones en un contexto determinado, el hombre tiene que "optar". Optar es propiamente "adoptar en esa acción una determinada forma de

12. A continuación se explican esos modos en que se expresa esa riqueza de actualización: el "me" y el "mi" hasta llegar al "Yo" (cfr. HD, pp. 57-58).

13. Y estas existen no solo de hecho, sino gracias al carácter de "especificidad" de la sustantividad humana (HD, p. 60). Una exposición más detenida de la "especie", en las páginas que siguen de HD, pp. 60-62.

14. Un análisis pormenorizado de estas dimensiones puede verse en la obra póstuma de $\mathrm{X}$. Zubiri, Tres dimensiones de ser humano: individual, social, histórica, Madrid, 2006.

15. En efecto, Ellacuría dice que "el ser del hombre, el ser de la sociedad y el ser de la historia se van realizando en la religación personal en su triple dimensión individual, social e histórica" (I. Ellacuría, "Introducción crítica a la antropología filosofía de Zubiri”, óp. cit., p. 134).

16. En este contexto, puede verse también A. Torres Queiruga, Filosofía de la religión en Xavier Zubiri, pp. 49-84. 
realidad entre otras". Cada cosa real le impone al hombre la "forzosidad de una forma de realidad. Su adopción entre las diversas formas de realidad es justo la opción”. Por eso el hombre es, además, autor de sus acciones (HD 78).

Por tanto, ejecutando acciones según estos tres modos es como el hombre "realiza" su vida personal. Con ello va "cobrando" su relativa absolutez (HD 78).

En este contexto, cabe la pregunta: ¿cómo se hace el hombre persona relativa en sus acciones? En la ejecución de sus acciones el hombre "cobra su carácter de relativamente absoluto". Este "cobrar" es algo propio de la persona humana, porque lo absoluto de su realidad consiste en "ser ab-soluto frente a todo" y a todos. Gracias a ese carácter se es persona humana. Cobrar significa ejecutar acciones "frente a todas las cosas" (HD 79). Sean éstas las cosas "apersonales, las demás personas, y hasta las mismas notas de mi propia sustantividad personal" (HD 80).

Ahora bien, estar con las cosas tiene una "ambigüedad" que necesita ser despejada. En la expresión "vivir es estar en sus acciones con las cosas", se manifiesta precisamente tal ambigüedad. Ahí aparecen el "con" y el "en" que expresan momentos distintos en toda acción. Y si bien estar "con" las cosas es importante, lo esencial, sin embargo, consiste en que con ellas donde el hombre está es en la realidad. Toda acción humana está en la realidad (HD 80).

Por tanto, "vivir es poseerse a sí mismo como realidad estando con las cosas en la realidad. Y este estar es lo que configura nuestra propia forma de realidad". Las cosas reales tienen la función de vehicular "la" realidad. En cada acción el hombre "tiene su posición 'en' la realidad". Él se funda en la realidad en cuanto realidad. "Sólo por eso puede ser persona. El 'frente a' es un aspecto de la 'fundamentalidad de la realidad" (HD 81). Después de haber clarificado lo anterior, se exponen las siguientes cuatro cuestiones (cfr. HD 81).

\subsubsection{Momentos de la fundamentalidad de lo real}

El hombre es persona por tener inteligencia sentiente. La intelección es la mera actualización del "de suyo" en la inteligencia. En consecuencia, "la realidad" es aquello en que de hecho y de modo constitutivo se "apoya" el hombre para ser persona humana (HD 81). Aquello en que él está es "la realidad". Por tanto, el "carácter de la realidad" en las acciones consiste en ser "apoyo" para ser persona. Tal apoyo consiste en "ser el fundamento de la persona" (HD 82).

Ese fundamento tiene sus momentos. El primero consiste en que la realidad en cuanto formalidad del "de suyo" es apoyo último en las acciones del hombre. Todo o casi todo puede fracasarle al ser humano, sin embargo, por ser realidad y mientras haya realidad siempre habrá una especie de última instancia para él. De lo cual se desprende que la realidad es apoyo "último" para el hombre: es la ultimidad de lo real (HD 82). 
El segundo momento se explica porque el hombre, en sus actos, opta por una posibilidad entre otras de las que la realidad le presenta para poder realizarse como ser relativamente absoluto ( $c f r$. HD 82). Aquí el momento de realidad es aquello que constituye "la posibilidad de todas las posibilidades". Por eso, el momento de realidad es también posibilitante; este posibilita que mi realidad sea "humana". Toda posibilidad tiene su fundamento en "la realidad como posibilitante" (HD 83).

Para el ser humano es inexorable ejecutar sus acciones para poder realizarse. Y tiene que realizarse por "imposición" de la realidad. Es lo que constituye el "apoyo" a la propia realidad del hombre en cuanto realidad suya. En este sentido, la realidad es impelente. Es la impelencia de la realidad en el hombre. La realidad impele a "esbozar un sistema de posibilidades entre las que el hombre tiene que optar y que constituyen la última instancia de su propia realidad". Por tanto, la "realización" de persona le está "impuesta" al hombre por la realidad. El hombre no sólo vive en y desde la realidad, sino también por ella (HD 83).

La fundamentalidad de lo real es, por tanto, la estricta unidad de "ultimidad (en), posibilitación (desde), y impelencia (por)" (HD 83-84). La realidad "funda" el ser de la persona según esos tres aspectos (HD 84).

Cabe notar todavía que en este fundar la realidad es una "paradoja". Lo es porque, por una parte, la realidad "es lo más otro que yo puesto que es lo que me hace ser", pero, por otra, esa misma realidad es "lo más mío porque lo que me hace es precisamente mi realidad siendo". Esa "extraña unidad" es lo que constituye la "paradoja del fundar". Es lo que hay que aclarar a continuación (HD 84).

\subsubsection{La realidad fundamento es el poder de lo real}

Dicho lo anterior, veamos la estructura de la fundamentalidad de lo real. La fundamentalidad es primaria y radicalmente fundamentalidad para la vida humana. El hombre se encuentra instalado en la realidad de tal manera que ella le determina "frente a" la realidad. Esta determinación real es dominación. Dominar es, ante todo, el hecho físico de "ejercer dominio" (HD 86).

Dominar es algo real de quien domina. Pues bien, la realidad que hace a los hombres "ser realidades personales es dominante", ejerce dominio sobre su ser. Evidentemente, la realidad solo se da en las cosas reales, pero es "más" que ellas. Se trata de un "más" intrínseco a las cosas reales. Por tanto, dominar es el ser "más" de la realidad en la cosa misma. La realidad en cuanto realidad es dominante "en cada cosa real". A este dominio se le llama poder ${ }^{17}$. Pues bien, dominar consiste en ser "más", es tener poder (HD 87).

17. Véase también D. Gracia, Como arqueros al blanco. Estudios de bioética, Madrid, 2004, pp. 17-26. 
Recordemos que la realidad es el "fundamento" de la realidad personal. Esto significa que la realidad "ejerce" sobre la persona un "poder". La realidad es el poder de lo real ${ }^{18}$. En consecuencia, "poder es la dominancia de lo real como real". El poder de lo real se "apodera" del hombre para que se haga persona. Dominancia es, pues, apoderamiento. ¿Cómo acontece tal apoderamiento? Veámoslo a continuación (HD 88).

\subsubsection{La religación ${ }^{19}$}

Ante todo, recordemos que el poder de lo real fundamenta a la persona "apoderándose" de ella. Tal apoderamiento es un momento intrínseco y constitutivo de la realidad personal. Se es realidad personal gracias a este apoderamiento, de tal manera que el poder de lo real es un "apoyo" para ser. El ser humano "necesita que le hagan hacerse a sí mismo", necesita de ese "impulso para estar haciéndose" ${ }^{20}$. Y justo este "impulso es intrínseca y formal versión al poder de lo real" (HD 92).

El apoderamiento me "implanta" en la realidad. "Este paradójico apoderamiento, al apoderarse de mí, me hace estar constitutivamente suelto 'frente a' aquello mismo que de mí se ha apoderado". Por tanto, el apoderamiento "acontece", dice Zubiri, "ligándonos al poder de lo real para ser relativamente absolutos". A esta particular "ligadura" se le llama precisamente religación ${ }^{21}$. Efectivamente, "religados al poder de lo real es como estamos apoyados en él para ser relativamente absolutos" (HD 92).

De alguna manera todo lo real queda afectado por la religación. Sin embargo, sólo en el hombre es formalmente religación. En efecto, sólo en él la religación es el "acontecer formal de la fundamentalidad" (HD 93).

18. Zubiri amplía esta cuestión en el "Apéndice 1: El poder de lo real” de HD, pp. 89-91. Véase también en IRE, pp. 198-199.

19. Sobre la importancia de esta cuestión, Torres Queiruga dice que "el tema de la religación es, sin duda, el más ligado con el nombre y con la obra de Javier Zubiri (sic). Eso no tiene por qué significar sin más que sea de hecho el más importante. Pero lo cierto es que la precoz y brillante entrada de la religación en la publicidad filosófica hizo de ella un punto de referencia inexcusable, constituyéndola en centro permanente de referencia. El resultado fue que el mismo Zubiri le consagró una atención sostenida, enriqueciéndola siempre con nuevos matices y perspectivas. De hecho, todo su tratamiento del problema de Dios está en gran medida determinado por ella" (A. Torres Queiruga, Filosofía de la religión en Xavier Zubiri, óp. cit., p. 49).

20. Sobre estas expresiones, véase EPD, en NHD, p. 428.

21. Se trata de un término que Zubiri "introduce" en el año de 1935; cfr. A. González, "Presentación", en PFHR, p. i; también EPD, en NHD, pp. 428-433. Religación "porque la realidad nos puede y nos ata, nos reata (eso es lo que significa el verbo religare en latín, reatar), estamos, querámoslo o no, reatados o unidos al poder de lo real, que se nos impone en su triple condición de 'último', 'posibilitante' e 'impelente'" (en D. Gracia, Como arqueros al blanco, óp. cit., p. 25). 
Esta concepción de la religación no es meramente teórica, sino que parte de un "análisis de hechos"22. La religación, efectivamente, es un hecho perfectamente constatable en la misma realidad humana ${ }^{23}$. Pero, además, la religación "es algo que afecta al todo de mi realidad humana desde mis más modestos caracteres físicos hasta mis más elevados rasgos mentales". Por tanto, la religación es también un hecho total, pues afecta de forma integral a la persona, le afecta en todas sus dimensiones. Finalmente, y sobre todo, la religación es algo "básico y radical"; es la "raíz" de la realidad personal del hombre. En efecto, la religación es la raíz que posibilita que cada persona llegue a ser no sólo un Yo, sino su Yo (HD 93).

\subsubsection{Religación, obligación y sentimiento de dependencia}

La religación no es mera obligación, porque ésta presupone a aquélla ${ }^{24}$. En efecto, si estamos obligados a algo es porque antes estamos "religados al poder que nos hace ser" 25 . Para estar obligados "tenemos que ser ya realidad personal", y solo lo somos por "estar religados" (HD 93). Mientras que en la obligación "vamos a" algo, en la religación, en cambio, "venimos de". Pues bien, en tanto "vamos" en cuanto "hemos venido". Más que la "obligación de hacer", pues, en la religación "hay el doblegarse del reconocer a lo que hace que haya" (HD 94).

22. Estamos ante un mérito original de Zubiri del que parte su aproximación metodológica a la religión, fundándola en el hecho universal de la religación. En efecto, la religión es la plasmación del hecho de la religación. Sobre la importancia de esta originalidad metodológica del filósofo, puede verse A. González, “Aproximación a la filosofía zubiriana de la religión", pp. 267-269.

En esa misma perspectiva hay que leer su trilogía sobre la inteligencia sentiente. En efecto, para Zubiri no se trata de "razonamientos conceptuales", sino de un "análisis de los hechos de intelección" (IRE, p. 14).

23. La religación "es una experiencia universal, que se podrá o no hacer consciente o elaborar temáticamente, pero que todo el mundo tiene" (D. Gracia, Como arqueros al blanco, óp. cit., p. 143).

24. En opinión de Diego Gracia, "Zubiri está a mil leguas de la identificación de moral y religión. Su tesis es que la forma originaria de la experiencia religiosa es la religación, y la de la experiencia moral la obligación. La primera tiene siempre un carácter prioritario respecto de la segunda. Esto significa que la obligación moral es siempre ulterior a la religación. Pero no significa necesariamente que los 'contenidos' morales tengan que venir determinados por las religiones. Para Zubiri los conceptos de 'religación' y de 'obligación' son 'formales' y 'trascendentales' y, por tanto, resultan independientes de cualquier contenido. La prioridad de la religión sobre la ética no conlleva necesariamente la afirmación de que los contenidos éticos o las normas morales hayan de venir directamente establecidos por la o las divinidades" (D. Gracia, Como arqueros al blanco, óp. cit., p. 147).

25. La religación "es el fundamento de toda 'obligación'. Estamos obligados porque estamos religados. Dicho de otro modo, el poder de lo real es el fundamento de nuestras obligaciones morales, de la promoción de los poderes positivos y la evitación de los negativos" (D. Gracia, Como arqueros al blanco, óp. cit., p. 25). 
La religación tampoco puede identificarse con el "sentimiento de dependencia incondicional". Ante todo, porque "todo sentimiento tiene un momento intrínseco y formal de realidad". Además, porque "para que haya un sentimiento de dependencia tiene que actualizarse el momento de realidad como algo a lo que estoy ligado, como algo anterior al sentimiento mismo". Finalmente, porque "toda dependencia incondicional presupone una realidad relativamente absoluta". Es otras palabras, "presupone la religación” (HD 94).

En definitiva, el hombre se encuentra religado al poder de lo real que se apodera de él. "La fundamentalidad acontece en la religación al poder de lo real". Esta unidad del poder de lo real y de la religación transcurre en el "apoderamiento" (HD 94). La religación es el fundamento de la obligación y del sentimiento de dependencia incondicional.

\subsubsection{Características de la religación}

En este contexto, se presentan tres características de la religación. En primer lugar, el ser humano "tiene experiencia de lo que es el poder de lo real, y por consiguiente una experiencia de lo que es la realidad misma como poder". Se trata, pues, del carácter experiencial de la religación (HD 95).

Aquí no se trata de la experiencia como dato sensible, ni como lo empírico, tampoco significa experiencia de la vida. Zubiri entiende la experiencia fundamentalmente como "una especie de prueba a que se somete algo". Es una prueba que consiste en "el ejercicio mismo operativo de probar: es probación física. ¿De qué? De la realidad física de algo. Por tanto, la experiencia es la 'probación física de realidad"” (HD 95).

Recordemos que el hombre va a la realidad en búsqueda de un "apoyo". Esta realidad encontrada es rica en notas y estas "son una talificación del momento de realidad, y por tanto quedan determinadas por este momento como posibilidades en la realización". Pues bien, la inclusión de "estas posibilidades en la realización de mi persona es la probación física de realidad". Por tanto, el hombre "haciendo religadamente su propia persona, está haciendo la probación física de lo que es el poder de lo real". En efecto, es la experiencia "de la inserción de la ultimidad, de la posibilitación y de la impelencia en mi propia realidad". Con lo cual, al "hacerme realidad personal soy pues una experiencia del poder de lo real, y por tanto de 'la' realidad". Es una experiencia que se despliega en las dimensiones individual, social e histórica del ser del hombre (HD 95).

En segundo lugar, la religación es una manifestación del poder de lo real. Entonces, la religación también es manifestativa. No se trata de algo conceptual, sino de una manifestación real. Y "todo lo real tiene un elenco de notas que constituyen su propia riqueza". En una o varias de estas notas se va "actualizando la realidad" de toda la cosa. Estas notas constituyen su "dimensión mani- 
festativa". El carácter manifestativo concierne a lo real en cuanto real. En este sentido, la religación es manifestación. "Y lo que así se manifiesta es el poder de lo real como religante" (HD 96).

En tercer lugar, como es una manifestación en la línea de la realización de la persona relativamente absoluta, esto pone de relieve que lo manifestado tiene también un carácter enigmático. La religación es la "experiencia que manifiesta lo enigmático" del poder de lo real. No olvidemos que estando con las cosas reales, el hombre está en "la" realidad. Y toda cosa real impone al ser humano que adopte una "forma de realidad". Aquí es donde precisamente aparece el "enigma" (HD 96).

Enigma significa fundamentalmente un "modo de significar lo real, pero no declarando lo que es sino tan sólo indicándolo significativamente" (HD 96-97). Enigma, pues, es un modo de manifestar la realidad. La realidad es enigmática porque, por una parte, es un momento de la cosa real concreta con que el hombre está. Pero, por otra, esta misma realidad le impone a él que adopte una "forma de realidad", no forzosamente la de esta cosa real, sino una forma de realidad en "la" realidad (HD 97).

Ambos momentos son inseparables, pero al mismo tiempo hay que sostener que son muy distintos. En efecto, toda cosa intelectivamente aprehendida "es real, pero ninguna es 'la' realidad". Sin embargo, la gravedad de la cuestión radica en que es precisamente "cada cosa real" lo que impone al hombre "estar en 'la' realidad". Esto porque las cosas reales son los "vectores" del poder de lo real. No se trata de dos realidades, sino de una sola. Es efectivamente una "unidad enigmáticamente manifiesta en nuestra religación experiencial". Es inexorable estar en la realidad. Es una exigencia de las "cosas reales en su realidad, pero ninguna es aquello en que se nos hace estar". Es precisamente el poder de lo real como enigma: "estar en 'la' realidad con las cosas reales. Es un poder enigmático" (HD 97).

Clarifiquemos un poco más. En las cosas reales hay ese momento de la realidad que es "más" que esta cosa real. Por ejemplo "ser verde real es más que ser verde real". La gravedad de esta cuestión radica en que "por ser 'más', ser real manifiesta la cosa como momento de 'la' realidad". Es evidente entonces que "esta" cosa real concreta (llámese verde real, por ejemplo), no es "la" realidad. Pero al mismo tiempo, "la" realidad está en "esta" realidad, pero lo está de modo enigmático. Y este enigma se manifiesta al hombre en la experiencia de la religación. Pues bien, la realidad es un "más", pero lo es no por estar encima de las cosas reales, sino en ellas mismas. Por tal razón, al estar con "esta" realidad particular, el hombre está en "la" realidad. Por lo mismo, "esta" cosa real puede imponerle al hombre que adopte una forma posible en "la" realidad. Se trata primariamente de un "carácter físico del poder de lo real" (HD 98). 
En definitiva, la religación consiste en el "estar apoderado por el poder de lo real". Por la religación los hombres están "físicamente lanzados hacia la realidad que se ha apoderado" de ellos de un modo manifestativo y experiencial. Pero como el poder de lo real es enigmático para la realización del hombre, resulta que también es "problemático". Es lo que toca analizar en la última cuestión (HD 99).

\subsubsection{Problematismo de la fundamentalidad}

El carácter problemático de la fundamentalidad de lo real tiene los siguientes tres momentos.

\section{(a) La inquietud de lo enigmático}

En el primer momento se constata que la realidad humana está "inquieta". Tal inquietud es la huella del "enigma de estar religado" (HD 99). Aquí se trata de una inquietud primaria. En efecto, si el hombre está inquieto es porque él "es en sí mismo inquietud". La vida de la realidad humana es vida "constitutivamente inquieta porque la realidad en que se vive es enigmática". Justo por ello, esta vida humana "padece de inquietud" (HD 100).

Esta inquietud se expresa en dos cuestiones innegables para el hombre: "¿qué va a ser de mí?". Esta primera pregunta cobra un sentido más urgente en la segunda: “¿qué voy a hacer de mí?”. Cada acción del ser humano incluye esta cuestión y es, en definitiva, una respuesta a tal pregunta. Por tanto, la "unidad de este hacer con vistas a mi realidad personal, y de esta realidad como algo hecho, es lo que constituye precisamente la inquietud". En definitiva, es la "inquietud por su propia realidad en cuanto apoderada ya por lo enigmático del poder de lo real". Se trata, por tanto, de la "inquietud de lo enigmático" (HD 100).

La inquietud puede vivirse como deslizamiento, como angustia y como preocupación (cfr. HD 100-101). Pero existe una forma elemental de vivir la inquietud que merece la pena destacar: es la ocupación. El hombre efectivamente "está ocupado en hacerse persona”. Es algo ineludible en toda acción humana (HD 101).

La inquietud así expuesta es algo primario y radical que emerge del hombre mismo, por el hecho de que en toda acción él cobra su "relativo ser absoluto". Y esta "relatividad" es justo la religación, la cual nos remite al poder de lo real que es enigmático y que es vivido en forma de inquietud por el ser humano (HD 101).

\section{(b) La voz de la conciencia}

Desde el segundo momento del problematismo de la fundamentalidad de lo real, puede afirmarse que la inquietud tiene en cierto modo su compensación en el innegable fenómeno de la voz de la conciencia. Ella está presente en cada instante de la vida del ser humano. "Es la voz que en una o en otra forma dicta al hombre lo que ha de hacer o no hacer". Se trata de un fenómeno real (HD 101). 
Es una voz que sale del "fondo" de la realidad de la persona. Ese fondo radical de la persona es el "carácter absoluto" de la realidad del hombre. "Y la voz que surge de este fondo es voz ante todo porque lo absoluto relativo es mío, soy yo mismo, y no otro". De ahí precisamente es que emerge la voz de la conciencia (HD 102).

La voz de la conciencia dicta algo que ciertamente puede ser diverso porque naturalmente cada cultura es diversa. Pero lo fundamental consiste en que en todos los dictados se trata de algo que emerge del fondo de la propia realidad humana, es precisamente una "forma de realidad" que ha de adoptar. "En esto consiste formalmente el dictado de la voz de la conciencia", ella dicta de un modo "inapelable e irrefragable" (HD 102).

La voz de la conciencia es, ante todo, una "voz", y esta es una forma de intelección sentiente. Los sentidos del hombre se distinguen por el modo particular de aprehender un contenido como algo "de suyo" (HD 103). Por ejemplo, en el oído el sonido está aprehendido como algo "de suyo". Aquí lo real está "notificado". El oído remite a la cosa sonora, es por tanto "noticia". Pues bien, la voz de la conciencia es precisamente "como una remisión notificante a la forma de realidad. Y aquello de que es noticia es la realidad". Desde esta perspectiva, el hombre es la "voz de la realidad". La voz de la conciencia es entonces el "clamor de la realidad camino de lo absoluto" (HD 104).

Esta voz "clama"; en otras palabras, lanza físicamente al ser humano "hacia el poder de lo real como enigma". Es justo la "voz del problematismo del enigma de lo real" hacia el cual está lanzado. Es precisamente en este sentido como el hombre está lanzado físicamente "hacia lo real en su realidad, por la voz de la conciencia" (HD 104).

\section{(c) Voluntad de verdad real}

Además de la inquietud de lo enigmático y la voz de la conciencia, el ser humano se encuentra ineludiblemente lanzado a "tener que determinar la forma de realidad que ha de adoptar": es justo la volición. Pero por ser animal de realidades, la tendencia humana es "tendencia a unas formas de realidad", entre otras. A la unidad interna de tendencia y determinación real Zubiri la llama volición sentiente. Y consiste en la "determinación tendente de forma de realidad". La volición consiste en los siguientes tres pasos (HD 104).

En primer lugar, el término de la volición radical consiste en que su modo de actualización es "estar fundamentando" al ser relativamente absoluto. Es la realidad como enigma cuya presencia consiste en "fundamentar": es la realidadfundamento $^{26}$. Ambos momentos expresan una única realidad. Los hombres no

26. Sobre la realidad-fundamento, puede verse también IRA, pp. 45, 48-52, 105, 130, $136,314$. 
solamente están "vertidos", sino también "lanzados" a la radical unidad de la "realidad-fundamento" (HD 105).

En segundo lugar, en virtud de la realidad-fundamento, el hombre está inexorablemente lanzado por la fundamentalidad a "adoptar una forma de realidad". Y como esta forma de realidad tiene que ser "optativamente determinada como una posibilidad, la determinación es adopción, es apropiación de una posibilidad" (HD 105). Es lo que en rigor constituye la volición: la "apropiación de una posibilidad de forma de realidad" (HD 105-106).

En tercer lugar, ¿en qué consiste fundamentalmente tal volición de forma de realidad? La volición se refiere a una adopción en virtud de la cual "se trata de tener actualizada" la realidad-fundamento. Esta voluntad radical es, en rigor, "voluntad de realidad personal", y engloba a la persona en su totalidad. Es voluntad de realidad. Esta realidad actualizada en la intelección es "verdad". Por tanto, la voluntad de realidad es voluntad de verdad. Ésta se refiere radicalmente a la "voluntad de ser una realidad meramente actualizada en mi intelección". Es la verdad real ${ }^{27}$. "Es verdad porque es una actualización intelectiva de la realidad, y es real porque lo actualizado es lo real mismo como algo "de suyo"” (HD 106).

La verdad real es manifestación (ser asî), es fidelidad (así sea) y es efectividad ("efectivamente está siendo"). La unidad de esos momentos constituye la "verdad real". Por tanto, la voluntad de verdad real es intrínseca y unitariamente manifestación, fidelidad y efectividad (HD 107) ${ }^{28}$.

Pues bien, la realidad-fundamento es verdad real según esos tres momentos. En nuestros días el ser humano necesita poner atención a la verdad real. Se trata de una voluntad de verdad que pretende descubrir cada vez "más manifestación, más seguridad, más efectividad de lo real". Por la verdad real el hombre está lanzado "hacia", a optar por una determinada realidad. Precisamente por esto, él "tiene que adoptar alguna forma de realidad entre otras posibles" (HD 107).

Como esta forma es optativa, la voluntad de verdad real se plasma en búsqueda. Búsqueda de "cómo se articulan las cosas reales en 'la' realidad para poder optar por una forma de realidad". El hombre necesita indagar la forma "cómo se articula en cada cosa 'su' realidad con 'la' realidad". Ésta es la fundamentalidad en que se fundamenta la realidad personal del hombre. Es una experiencia de "búsqueda de fundamento". Es lo que con más precisión se llama experiencia teologal. Lo teologal es lo que implica la "versión" del ser humano a la cuestión de Dios (HD 108).

27. Sobre el importante tema de la verdad real, véase la exposición madura de Zubiri en IRE, pp. 229-242; IL, pp. 257-259; IRA, p. 259.

28. Sobre estas cuestiones, véase el “Apéndice 8" de Zubiri en IRE, pp. 243-246. 
Resumiendo, podemos afirmar que el problematismo de la fundamentalidad de lo real está constituido por la inquietud de lo enigmático, por la voz de la conciencia y por la voluntad de verdad real.

En definitiva, hemos presentado en esta primera sección la realidad humana y la religación desde la perspectiva de Zubiri. Esta concepción es precisamente la que sirve de marco referencial maduro para exponer y encuadrar, a continuación, la cuestión de la religación como actitud radical del ser humano, según Ignacio Ellacuría.

\section{La religación, actitud radical del hombre en I. Ellacuría ${ }^{29}$}

Con esta segunda sección de nuestro trabajo, queremos rememorar el vigésimo aniversario de la muerte martirial de Ignacio Ellacuría (1989-2009), desde su cercana relación con Xavier Zubiri. Tal relación aparece, a nuestro modo de ver y en este caso concreto, en esa preocupación radical y última de Zubiri por desbrozar el significado de la realidad humana y la religación, y por esa recepción mostrada en Ellacuría al captar tempranamente la fundamentalidad de la religación como actitud radical del hombre. Se trata, pues, de una cercanía en el ámbito de la filosofía antropológica en la que ambos pensadores mostraron un interés particular $\mathrm{y}$, por lo mismo, dedicaron importantes y novedosos trabajos ${ }^{30}$.

La tesis de Zubiri, que Ellacuría recoge y expone en esta sección, expresa precisamente que la religación es la "actitud radical de la vida humana". Es lo que pretende explicar a continuación (RARH 39) ${ }^{31}$.

El autor desarrolla el tema en tres apartados. En el primero, presenta al hombre como realidad religable. En el segundo, expone la realidad humana en cuanto realidad religada. Y en el tercero, muestra que la religación es la actitud radical del hombre.

29. I. Ellacuría, "La religación, actitud radical del hombre (Apuntes para un estudio de la antropología de Zubiri)", Asclepio 16 (1966), pp. 97-155. Posteriormente, este trabajo fue reproducido en su obra póstuma I. Ellacuría, Escritos teológicos I, San Salvador, 2000, pp. 39-105; aquí seguimos esta última reproducción.

Sobre la religación como actitud radical del hombre, puede verse también nuestro trabajo H. C. Gudiel García, La fe según Xavier Zubiri. Una aproximación al tema desde la perspectiva del problema teologal del hombre, pp. 196-207; también PFHR, pp. 29-60.

Una visión amplia de la filosofía de Ellacuría, en H. Samour, Voluntad de liberación. La filosofía de Ignacio Ellacuría, Granada, 2003.

30. Sobre el carácter antropológico de los escritos de Ellacuría pueden verse varios de los artículos recogidos en I. Ellacuría, Escritos filosóficos II, San Salvador, 1999.

31. A partir de este momento, las notas que se refieran a este artículo de Ellacuría irán en el interior de nuestro texto, entre paréntesis, con la sigla RARH y, a continuación, la página o las páginas correspondientes. 


\subsection{El hombre, realidad religable ${ }^{32}$}

Las ideas que a nuestro juicio vale la pena destacar en esta sección son el hombre como realidad apoyada, la ultimidad de la religación, la religación y la religión, y, por último, la religación y el fundamento.

\subsubsection{El hombre, realidad apoyada}

Aquí se parte de lo más radical de la realidad del hombre afirmando que él es "personeidad". La personeidad no es algo que se adquiere, pues se la tiene ya "recibida" (RARH 46). Y por ser acto primario, la personeidad se concreta en la personalidad. Hay una inexorable necesidad de que la realidad humana se realice. La personeidad se actualiza en la personalidad. Dice Ellacuría que para Zubiri "el hombre existe ya como persona, en el sentido de ser un ente cuya entidad consiste en tener que realizarse como persona, tener que elaborar su personalidad en la vida" (RARH 47) ${ }^{33}$.

El hombre ha de realizarse con la vida que se le aparece como "enviada", como algo "impuesto". Impuesto en el sentido preciso de verse "impulsado". $\mathrm{Y}$ "lo que le impulsa a vivir como persona es algo en lo que el hombre se apoya como realidad". Es que efectivamente el hombre "no se basta a sí mismo" (RARH 47).

Ellacuría afirma que para Zubiri "el hombre, al existir, no sólo se encuentra con que 'hay' que hacerse y 'ha' de estar haciéndose. Además de cosas, 'hay' también lo que hace que haya" 34 . Este texto es fundamental porque sitúa con claridad el problema en el ámbito de lo que "hay". En efecto, se vincula en modo definitivo la cuestión de la "religación con el problema de la realidad" (RARH 48). En consecuencia, en la religación estamos primariamente ante una "aprehensión simple" (RARH 49).

Por tanto, el ser humano está "ante la realidad de las cosas, ante la realidad del hacerse, ante la realidad del 'haber' de hacerse y ante la realidad de lo que

32. En esta primera sección, Ellacuría sigue el trabajo que primeramente Zubiri había publicado en español, en el año de 1935, en la Revista de Occidente número 149. Una segunda versión del mismo fue una "traducción francesa" que resultó defectuosa y de la que Zubiri mostró su "total desaprobación". La tercera redacción se basa en aquel "texto español que sirvió de base” y que Zubiri “ofrece en estas páginas” (EPD, en NHD, p. 418, "nota aclaratoria"), titulado "En torno al problema de Dios", en NHD, pp. 417-454.

33. En el texto de Zubiri, la expresión "tener que realizarse" aparece en cursiva. Tal subrayado tiene su importancia en EPD, en NHD, p. 427.

34. El texto completo de Zubiri dice así: "El hombre, al existir, no sólo se encuentra con cosas que 'hay' y con las que tiene que hacerse, sino que se encuentra con que 'hay' que hacerse y 'ha' de estar haciéndose. Además de cosas, 'hay' también lo que hace que haya" (EPD, en NHD, p. 428). 
hace que haya". Esto significa que el planteamiento está en el horizonte "primario de realidad" y que los cuatro momentos diferenciados tienen ese sentido "metafísico de realidad". El hombre se encuentra, pues, como una realidad personal apoyada en la realidad para hacerse persona (RARH 49).

\subsubsection{La ultimidad de la religación}

Ese apoyo del hombre no es primariamente obligación moral, porque la obligación no es el dato último de la experiencia humana. Si él está obligado es porque previamente está religado a lo que le hace existir. "Ese vínculo ontológico del ser humano es "religación"” (RARH 50) ${ }^{35}$.

En la religación el hombre está ante una dimensión primaria y radical, al hallarse, por ella y en ella vinculado a lo que le "posibilita y fuerza a una vida personal". En la religación también "hay el doblegarse del reconocer ante lo que "hace que haya"'. En virtud de la religación se "nos hace patente y actual la fundamentalidad de lo que es la vida personal humana". La religación nos sitúa en el ámbito de la "fundamentalidad, de lo fundamentado y del fundamento" (RARH 51) ${ }^{36}$.

Es menester preguntarse por lo que fundamenta a la persona. Solo de esa manera habremos llegado al "último fundamento de lo que es la vida humana". Precisamente por eso, preguntarse por la religación significa preguntarse por la "raíz y el apoyo de nuestra vida personal". Lo que es la vida humana tiene que mostrarse inevitablemente como "vivir 'con', con cosas, con otras personas" y consigo mismo. He aquí el "planteamiento radical de la realidad humana y, por tanto, en él ha de aparecer el tema de la religación que afronta la ultimidad radical de la realidad humana" (RARH 52).

Ciertamente, la religación afecta a todas las cosas reales, sin embargo, solo en la realidad humana se actualiza formalmente. Pero justo en esa actualidad formal se manifiesta todo lo real "como un campo iluminado por la luz de la fundamentalidad religante" (RARH 52) ${ }^{37}$. La apertura del hombre a las cosas reales se realiza propiamente por la "nota de realidad". Y precisamente en este "carácter de realidad es donde se manifiesta la religación" (RARH 53).

Por tanto, la vida humana es algo que aparece "formalmente religado", de modo que la religación es una dimensión constitutiva de la vida humana (RARH 53). "Solo en esta dimensión de ultimidad, que es la fundamentalidad y la religación, aparecen las raíces últimas de lo que es el hombre". Y esto es "es algo que se es" (RARH 54).

35. Véase EPD, en NHD, p. 428.

36. "Fundamento es, primariamente, aquello que es raíz y apoyo a la vez" (EPD, en NHD, p. 429).

37. Véase EPD, en NHD, p. 429. 


\subsubsection{Religación y religión}

Pues bien, a esta dimensión anteriormente expuesta se orienta propiamente el fenómeno religioso ${ }^{38}$. La re-ligión ha de ser últimamente re-ligación. En efecto, "sólo quien por su vida personal pueda actualizar su presunto estar religado es capaz de religión, lo cual es aún más claro si esta religión toma forma de revelada" ${ }^{39}$. Ellacuría dice que "retrotrayendo la religión a la religación se la sitúa en su ámbito propio", el ámbito de su "totalidad y ultimidad personales" (RARH 54).

La dimensión radical de la religación afecta al hombre en su aspecto personal de lo que es. En efecto, "es la índole de nuestra personalidad la que envuelve formalmente la religación". Por tanto, la religación es "el fenómeno primario en que se actualiza" el ser personal del hombre. De ahí que la religión pueda considerarse fundamentalmente como "una dimensión formal del ser personal humano". La religión en cuanto tal es la "actualización del ser religado del hombre" (RARH 55).

En la religión sentimos, ante todo y sobre todo, "un fundamento para ser". Radicalmente hablando, la religión es una "estructura física y metafísica del ser humano que aparecerá necesariamente en la vida personal humana, siempre que se alcance una auténtica vida personal, en la cual la persona aparezca y se actualice como un absoluto relativo". Cuando el ser humano se "enfrenta con su propio ser ligado y lo reconoce y acata como tal, entra en el ámbito de lo religioso, cobre después éste la forma concreta que sea". Lo cual clarifica "hasta qué punto y en qué sentido pueden darse verdaderas y falsas religiones sin dejar de ser auténticamente religiones" (RARH 55).

Como dimensión antropológica, pues, la religión ha de comprenderse últimamente desde la perspectiva de la religación. Ha de entenderse como "actualización del ser religado, a la luz de la fundamentalidad religante, de lo que fundamenta la vida personal en cuanto tal, que ha de acatar su propio fundamento". Este fundamento es la realidad que se actualiza en la inteligencia humana (RARH 56).

38. Sobre el tema, puede verse también S. Yáñez, "Desafíos del diálogo interreligioso. El aporte de Zubiri”, en F. Berríos, J. Costadoat y D. García (eds.), Signos de estos tiempos. Interpretación teológica de nuestra época, Santiago de Chile, 2008, pp. 189-210. Véase también J. Corominas, Zubiri y la religión, Puebla, 2008.

39. En este contexto recojamos lo que el mismo Zubiri dice: "Y, desde el punto de vista cristiano, es evidente que sólo el hombre es capaz de Revelación, porque sólo él consiste en religación: la religación es el supuesto ontológico de toda revelación" (EPD, en NHD, p. 430). Sobre la revelación en Zubiri, véase A. Torres Queiruga, Filosofía de la religión en Zubiri, pp. 85-99. 


\subsubsection{Religación y fundamento}

La religación de inmediato implanta al hombre en la dimensión de la realidad que lo fundamenta. El acercamiento del hombre a la divinidad es primariamente por el atributo de la fundamentalidad. Y "el atributo primario, quoad nos, de la divinidad es la fundamentalidad" (RARH 56) ${ }^{40}$.

El ser del hombre está afectado y en tal afección se patentiza Dios como "fundamentante, de suerte que la forma de su patencia sería la de estar fundamentado. Esta fundamentalidad 'pertenece' al ser del hombre, porque formalmente es un ser religado, un ser fundamentado". El hombre está en el fundamento, y por esa razón él "está viniendo desde su fundamento, 'teniendo que' hacer y hacerse". Así, "todo ulterior ir hacia su fundamento es un ser llevado por él" (RARH 57).

La religación se presenta ineludiblemente como una apertura singular en virtud de la cual el ser humano "se aparece a sí mismo como quien está puesto, como quien está viniendo desde su fundamento. Su implantación en la realidad tiene ese matiz del 'desde"'. De esta manera, la cuestión del fundamento se convierte en la "radical cuestión antropológica". Y la cuestión última del hombre es una cuestión "fundamental" (RARH 57). Desde esta perspectiva, la aproximación primaria a Dios será "en cuanto es fundamento de nuestra vida personal, tal como aparece en nuestra constitutiva religación" (RARH 58).

De esta manera, la realidad humana en cuanto realidad religada es el "lugar de patencia del fundamento" $"$. Lo que de fundamento hay en el ser humano "es tan sólo religación en la que es abierto a él, y en esta religación se le patentiza el fundamento". El modo primario de patentizar el fundamento es, ante todo y sobre todo, un acto de intelección de las cosas en su realidad (RARH 58).

En resumen, el hombre es realidad religable, es decir, es realidad apoyada en la ultimidad de lo real. Ahora bien, el ser humano también es realidad religada. Veámoslo.

\subsection{El hombre, realidad religada ${ }^{42}$}

Recordemos que se pretende clarificar la realidad del hombre en su dimensión última y radical: la religación. Es la dimensión que vibra cuando algo conmueve al ser humano en sus profundidades ( $c f r$. RARH 59). En este contexto puede afirmarse que "el hombre pre-sabe que alguien viene". Desde tal perspectiva, el problema es el de "la unidad radical de la realidad humana en cuanto

40. Véase EPD, en NHD, p. 432.

41. Esta cursiva es nuestra.

42. En esta sección Ellacuría sigue muy de cerca el trabajo que Zubiri había publicado en el año de 1963: "Introducción al problema de Dios", en NHD, pp. 393-416. 
realidad". Este problema surge de un "análisis de la existencia humana" (RARH 60).

El hombre ejecuta sus actos sobre cosas concretas, pero los realiza como persona. Lo cual modula decisivamente el "cómo de la ejecución de sus actos". Lo que aquí interesa destacar es la posición que a través de los actos va tomando el ser humano respecto de la ultimidad. Porque él es una realidad rigurosamente personal. Y por serlo se "halla constituida como algo de 'suyo', y, por tanto, enfrentada con el todo del mundo en forma, por así decirlo, 'absoluta'”. De ahí que los actos del hombre sean la "actualización de este carácter absoluto de la realidad humana”. He ahí la ultimidad (RARH 60).

En otras palabras, en los actos humanos en cuanto personales es menester atender también, y sobre todo, a lo que tales actos son en cuanto "objetivación de la posición que va tomando el hombre a través de sus decisiones". Este aspecto de sus actos personales es lo propiamente último. Lo último y decisivo en un doble sentido. Según el primero, "en cuanto que por ser aquello a que apuntan los actos personales [...] ha de ser lo apuntado algo que excede y sobrepasa toda posible concreción". El segundo sentido "en cuanto que en ese aspecto personal de los actos humanos se refleja formalmente el carácter de personal en cuanto tal, por lo tanto, algo que es 'suyo', algo que es 'ab-soluto' frente a todo lo demás, algo en lo que últimamente ha de apoyarse el hombre". Ellacuría resume lo anterior afirmando que "la actuación de la persona en cuanto persona es lo que nos sitúa ante la ultimidad, y la ultimidad solo se nos descubre en la actuación de la persona en cuanto persona" (RARH 61).

De lo anterior se desprende que la ultimidad se nos manifiesta como "fundante de nuestra actuación personal". Solo desde la dimensión personal logra su debido "carácter último la ultimidad de la realidad". Pero al mismo tiempo hay que señalar que es propiamente lo "personal lo que modula últimamente la ultimidad" (RARH 61).

Por ese doble carácter de la ultimidad, la persona se haya "apoyada en la ultimidad como en algo 'sólo por lo cual y desde lo cual es en sus actos aquello que puede ser, que tiene que ser y que efectivamente es"' ${ }^{43}$. Por lo mismo, si la realidad del hombre "es por el contenido diverso de sus actos una realidad actuante, en una u otra forma, por el carácter último de su decisión personal y de las condiciones que lo posibilitan será una realidad apoyada, fundamentada en la ultimidad". En este sentido, Ellacuría dice que para Zubiri "la religación no es sino el carácter personal absoluto de la realidad humana actualizado en los actos que ejecuta. El hombre está religado a la ultimidad porque en su propia índole es

43. En este contexto merece la pena citar a Zubiri, donde afirma precisamente que "este carácter fundante hace que el hombre en sus actos no sea sólo una realidad actuante en una u otra forma, sino una realidad religada a la ultimidad" (IPD, en NHD, p. 411). 
realidad absoluta en el sentido de ser algo "suyo". Al mismo tiempo, la "ultimidad es lo religante". Con lo cual puede afirmarse que la "religación es la unidad de la persona en cuanto persona humana religada y de la ultimidad en cuanto fundamento y apoyo de la actuación personal del hombre. Sólo a este nivel nos encontramos con la dimensión última del hombre" (RARH 62).

Esto posibilita que en "la religación seamos 'viniendo' religadamente de una ultimidad". Con lo cual esta ultimidad se nos abre primariamente a través de una dimensión rigurosamente "personal", por "algo que sea la realidad misma de la persona en cuanto tal" (RARH 62). Por ello, el hallazgo de la religación necesita de una operación rigurosamente intelectual. "Una operación que puede considerarse como un análisis discursivo. El término de ese análisis es la simple mostración de la religación" (RARH 63).

Esto clarifica, ante todo, que la religación tiene que considerarse como algo "presente a una inteligencia". Al mismo tiempo manifiesta "por qué esa ultimidad se nos presenta todavía un tanto indiferenciada". Por último, nos "sitúa en el punto preciso y actual para sentirnos lanzados a ejecutar nuestro razonamiento en la determinación precisa de esa ultimidad en cuanto religante, sin cuya determinación nosotros mismos quedaríamos últimamente indeterminados" (RARH 63).

\subsection{La actitud radical del hombre: religación ${ }^{44}$}

Cuatro son las cuestiones que Ellacuría presenta en esta sección. La primera, qué es una actitud personal. La segunda, cuál es la actitud personal radical. La tercera, cuál es el objeto y la estructura de la realidad término de esa actitud. Y la cuarta, cómo aparecen las cosas, y el hombre entre ellas, desde el punto de vista de la religación (RARH 64) ${ }^{45}$.

44. A partir de esta sección, Ellacuría expone la religación tal como aparece en los dos cursos en los que Zubiri había presentado el tema en "términos muy semejantes". El primero se refiere a "El problema filosófico de la historia de las religiones", Madrid, 1965. El segundo curso trata de "El problema de Dios en la historia de las religiones", Barcelona, 1965 ( $c f r$. PFHR, p. 29, nota 1). El curso de Barcelona, siendo del mismo año, es, sin embargo, posterior al de Madrid ( $c f r$. PFHR, p. 29, nota 1). Siguiendo fundamentalmente la "versión del curso de Barcelona", que "incluye las correcciones que Zubiri hizo sobre el texto mecanografiado de Madrid", se publicó el tema en la obra póstuma de X. Zubiri, El problema filosófico de la historia de las religiones, Madrid, 1993; véase PFHR, pp. 29-60. Naturalmente, es necesario precisar que "la exposición más acabada de la religación es la que se encuentra en X. Zubiri, El hombre y Dios, Madrid, 1984, especialmente en las pp. 75-112” (PFHR, p. 29, nota 1). Justo por esto, la primera parte de nuestro trabajo aparece como el marco a partir del cual debe ser entendida esta segunda parte en la que presentamos a Ellacuría.

45. Puede verse también PFHR, p. 29. 


\subsubsection{Qué es una actitud personal}

Para exponer adecuadamente lo que significa una actitud personal vamos a presentar la personeidad, la personalidad y la actitud.

\section{(a) La personeidad}

Aquí se parte de la consideración de que el hombre es una realidad personal, y se afirma que lo que le constituye como tal es la inteligencia (cfr. RARH 64-65).

La inteligencia es la capacidad que el ser humano tiene de "habérselas con todo como realidad". En virtud de la inteligencia, el hombre se comporta consigo mismo, por "esa capacidad de enfrentarse con las cosas y consigo mismo, en tanto que realidad". El hombre es una realidad dotada de algunas cualidades que le competen "de suyo". Pero también es una realidad que se pertenece a su propia realidad. "Este carácter de pertenecerse a sí mismo como realidad, y en tanto que realidad, es el carácter de personeidad" (RARH 65) ${ }^{46}$.

Gracias a su inteligencia, el hombre está "instalado e implantado en la realidad" (RARH 65). Por estar implantado en la realidad de las cosas, él se encuentra inquieto entre ellas. Pero no es una inquietud cualquiera. En rigor se trata de la inquietud "metafísica, nacida de la implantación del hombre en la realidad de las cosas". En efecto, al ejecutar sus actos personales el hombre "va trazando el camino de su vida". De este modo la vida se hace con. Esto significa que la vida se hace con las cosas reales, consigo mismo y con las demás personas. La vida implica constructivamente el carácter del "con". Por tanto, todo el decurso de la vida es el "transcurso de la manera como el hombre se posee efectivamente a sí mismo" (RARH 68).

Este poseerse del ser humano es el que nos ubica en el ámbito de lo personal (cfr. RARH 69).

\section{(b) La personalidad}

En su vida personal el hombre no sólo se ejecuta como persona, sino también se realiza como tal. En todo acto personal, el hombre no sólo se encuentra con aquello que hace, sino que también compromete su "yo" en la acción. Quien realiza tal o cual acción es el "yo". Presuponiendo su realidad sustantiva, el yo la reactualiza y la afirma. Su "yo" es su "ser sustantivo" ${ }^{77}$. El "yo" es la personeidad actualizada ulteriormente (RARH 69).

46. Esta última cursiva es nuestra.

47. Como puede verse, Ellacuría todavía sigue a Zubiri en la utilización de la expresión "ser sustantivo". Pero, como sabemos, el mismo Zubiri precisó esta expresión en sus escritos de madurez y la sustituyó por la de "ser de lo sustantivo" (cfr. IRE, p. 222; IL, p. 353; y HD, p. 54). Por tal razón, a partir de este momento, completaré la expresión con las palabras que faltan, añadiéndolas entre corchetes cuando aparezca la expresión incorrecta. 
El "yo", pues, es la actualización de la realidad sustantiva del hombre. Efectivamente, lo que hace el "yo" es "revertir por identidad, en acto segundo, a la realidad sustantiva de la que emerge". En eso consiste la intimidad (RARH 69). En otras palabras, "el momento de ser mío es aquello en que consiste formalmente mi intimidad" (RARH 69-70).

Lo que el "yo" va realizando en el transcurso de la vida es, o puede ser, muy variado. En cambio la personeidad es siempre la misma. Pero esto no significa que se trate de dos dimensiones separadas. En todos los actos personales se va modulando la figura del "yo". En efecto, el hombre va "configurando" en el trascurso de su vida su propio ser. Esta forma y figura de ser que el hombre va cobrando en el ejercicio de sus actos es precisamente la personalidad (RARH 70).

En consecuencia, en la vida personal se pone en juego la realización del hombre como persona. La gran cuestión para el hombre es "qué va a ser de mí, cuál va a ser mi ser. Y ahí está radicada la inquietud fundamental de la persona humana". En efecto, "la cuestión de la figura que va cobrando el ser [de lo] sustantivo en el ejercicio de los actos de la realidad sustantiva es lo que constituye formalmente la inquietud constitutiva y constante de la vida humana". Última y radicalmente lo que tiene inquieto al ser humano "es la propia realidad frente a la cual y desde la cual, va cobrando la figura de su ser" (RARH 71).

\section{(c) La actitud}

Ahora bien, “si el 'yo' va a adquirir una determinada configuración por los actos que realiza y en las actos en que se realiza, es preciso reconocer una versión determinada del 'yo' a sus actos”. Esta versión es lo que se llama una actitud (RARH 71).

“La actitud es la versión del 'yo' que va a cobrar una cierta forma en los actos que va a ejecutar, la versión del hombre hacia la configuración de su ser". Esta versión queda, al mismo tiempo, modulada por nuestras decisiones y su contenido. De ahí el valor de la "actitud y de las actitudes" (RARH 71).

Y "de ahí también la importancia de los actos mismos. El transcurso de la vida no es sino el recorrer de los actos del hombre" (RARH 71). Con lo cual puede decirse que la vida es constitutivamente "misión". Es la misión de ir configurando "el ser [de lo] sustantivo del yo". Por tanto, la vida es la "misión fáctica del ser" (RARH 72).

Expuesta qué es la actitud personal, veamos cuál es la actitud personal radical.

\subsubsection{Cuál es la actitud personal radical}

Aquí se trata de enfrentarse con esta pregunta, clarificando de que se busca la actitud que "subyace a todas las demás actitudes y en virtud de la cual, las demás actitudes han de considerarse como actitud” (RARH 72). 
Recordemos que el hombre hace su vida con la cosas, pero propiamente la hace en y con la realidad de las cosas (RARH 72). El hombre está implantado en la realidad. Por tanto, es en la realidad en cuanto realidad, como él "va a configurar el ser de su propia realidad sustantiva". En efecto, es la realidad la que lo "impulsa a hacerlo" (RARH 73). Este impulso cobra la forma de "apoyo" para que el hombre se realice. Él se encuentra "apoyado" en la realidad de donde le viene la vida y también le viene "su apoyo para ser persona" (RARH 74).

La realidad como apoyo tiene tres momentos. Ante todo, afirmar de algo que es real es lo último que puede afirmarse de ese algo y lo más "transcendental" (RARH 74). Solo cuando el hombre se enfrenta con la realidad llega a lo último. Además, la realidad es la que "posibilita que el hombre vaya cobrando la figura de su ser". Pero la realidad no solo es lo último y lo posibilitante, también es aquello que "impulsa al hombre a realizarse". La realidad se le "impone" [impele] intelectivamente al ser humano ${ }^{48}$. Naturalmente, este carácter de la realidad es algo que se refleja en la propia vida del hombre (RARH 75).

Pues bien, estos momentos de ultimidad, posibilitación e imposición [impelencia] son los que justamente caracterizan a la realidad, y también a la realidad que "soy yo". Por ello la realidad cobra una sutil dualidad. En efecto, "siendo lo más nuestro, puesto que nos hace ser, es, en cierto modo, lo más otro, puesto que nos hace ser". Es "nuestra propia realidad, la que nos hace ser". Es efectivamente ella la que "últimamente nos posibilita y nos impone [impele] la realización de nuestra propia realidad, en la configuración de su ser". Esto "supone que en esa misma realidad que somos nosotros aparece una sutil paradoja: la de ser lo más nuestro [...] y, por otra parte, algo que está como sobre nosotros (RARH 76).

Indudablemente, aquí estamos en lo último y radical. Por tal razón, estos tres caracteres tomados en su unidad encuadran la actitud radical del hombre. Porque este se ve "forzado a ir configurando su ser [de lo] sustantivo en virtud, precisamente, de esos tres momentos que posee la realidad misma. Y cualquier otra actitud ha de estar radicada en esta última, que lo es por surgir del carácter último de realidad y de aquellos sus momentos últimos sin los cuales no habría ni posibilidad ni fuerza para ir configurando el propio ser" (RARH 76). Ahora bien, "toda actitud dice referencia necesaria a esta configuración, y, por consiguiente, ha de estar radicada en esa actitud" descrita (RARH 76-77).

48. Como puede verse, Ellacuría sigue a Zubiri, quien todavía en 1965 habla de "imposición”. En cambio, "en el curso de 1968 Zubiri habla ya de impelencia". Sobre esa precisión de Zubiri, véase también HD, pp. 83-84 y 108-109 (PFHR, p. 39, nota 1). Por tal razón, pondremos entre corchetes la palabra más madura, "impelencia", cuando el contexto así lo reclame. 
Así pues, la religación es la actitud radical del hombre. La religación es la "ligadura a la realidad en cuanto realidad para ser" . En la religación acontece la fundamentalidad del "ser [de lo] sustantivo" del hombre. De esta manera, la religación queda planteada en el ámbito de la actitud radical del hombre. Y al mismo tiempo, esta actitud queda formulada en el ámbito de la "versión de la realidad sustantiva a la configuración de su propio ser personal" (RARH 77).

Por tanto, el fundamento o la "raíz y el apoyo de esta actitud radical es la realidad en su triple momento" (RARH 77-78).

\subsubsection{La estructura de la religación y de su término}

\section{(a) El poder de la realidad}

Para clarificar esta tercera cuestión recordemos, ante todo, que en la "religación acontece la fundamentalidad del ser [de lo] sustantivo del hombre". Esto gracias a los tres momentos que tiene la realidad como fundamento. Pero además, cabe destacar que el carácter de realidad no es algo meramente abstracto, sino algo que se refiere a la realidad misma (RARH 78).

La realidad tiene un carácter en virtud del cual se nos manifiesta: el de su "intrínseca respectividad". Gracias a la respectividad, las cosas constituyen un "mundo". Lo cual significa que la realidad no se nos presenta como algo disgregado y extrínseco, sino con "intrínseca respectividad". En efecto, "la realidad de cada cosa real intramundana dice intrínseca respectividad a la realidad de cualquier otra cosa intramundana, precisamente en cuanto realidad intramundana". Esto pone de manifiesto cómo la presencia de la realidad en sus tres momentos es algo "intrínseco" a la propia realidad humana (RARH 78).

Pues bien, la realidad en cuanto última, posibilitante e imponente [impelente], entendida en el contexto de la respectividad y la religación, se presenta al hombre como lo "dominante" (RARH 78-79). Este carácter de dominante es justo el "poder de la realidad". Por tanto, este poder de la realidad es la dominancia de lo real. Es lo real en sus tres momentos lo que se nos presenta como "dominante" (RARH 79). Es algo que le concierne a la realidad por el hecho de ser real (cfr. RARH 79-80).

Lo real tiene esa capacidad para dominar al hombre y a tal capacidad se le llama condición. "La condición es la capacidad de lo real para ser sentido". En cuanto tal, la realidad "tiene una condición que la afecta y en virtud de la cual es dominante. Esta condición de dominancia real es el poder". Por ello, el poder es la "condición dominante" de lo real en cuanto real. Por lo tanto, el poder afecta a la actitud del hombre y también a la estructura de las cosas en cuanto reales (RARH 80).

49. La cursiva es nuestra. Véase también PFHR, p. 40. 


\section{(b) Deidad y religación}

A ese poder en cuanto último, posibilitante e imponente [impelente] se le llama precisamente deidad $d^{50}$. La deidad no se identifica con Dios, sino que es la "realidad en cuanto poder". El ser humano ha "sentido siempre como un poder de deidad ese carácter universal y dominante que la realidad, en cuanto tal, tiene". Pero además, sólo desde la perspectiva de la deidad podremos ponernos en marcha hacia la realidad de Dios (RARH 80).

La deidad no es algo distinto al mundo y a las cosas reales. La deidad "es tan sólo la condición que las cosas reales tienen, por el mero hecho de ser reales, de tener un dominio las unas sobre las otras, y todas ellas sobre el hombre" (RARH 80-81). En efecto, la deidad es la realidad en su condición de poder. Esto no es una teoría, sino un hecho y la constatación de que en el hombre acontece el "poder de la realidad". El poder de la deidad está inscrito en las mismas cosas reales (RARH 81).

Pero justo porque el poder de la deidad está inscrito en las cosas reales, indudablemente la realidad estará afectada en su realidad por lo que las cosas son. Y al mismo tiempo "lo que las cosas son estará modulado por la transcendentalidad concreta de la realidad". Esto permite distinguir dos dimensiones del mismo problema. Por un lado, "la historia del problema de Dios, en tanto que enriquecimiento de la deidad, como poder de la realidad". Y, por el otro, la "historia del problema de Dios, en tanto que descubrimiento de Dios". Ambas dimensiones son separables (RARH 81). En este contexto puede afirmarse que la historia de las religiones ha sido "el lento y progresivo camino por el que el hombre ha ido actualizando ante su mente las complejas dimensiones que posee el poder de la deidad" (RARH 82).

Existen distintas dimensiones en que se ha puesto de manifiesto históricamente el poder de la deidad ( $c f r$. RARH 82-84) $)^{51}$. Sin embargo, no puede estarse seguro de si la historia ha conseguido ya "todas las dimensiones que son propias de la deidad". Pero es precisamente la historia de las religiones la que sirve para "ejemplificar el poder de la realidad en cuanto tal, la deidad". Lo cual pone de manifiesto que, en su diversidad, la "deidad es un todo funcional" (RARH 84).

La complejidad de las dimensiones del poder de la realidad queda contenida en el carácter último, posibilitante e imponente [impelente] de la realidad. Obviamente, estas dimensiones son de la realidad y no creación de la subjetividad humana. Esto es así porque "el poder es una condición de la realidad" y no algo

50. Véase también PFHR, p. 43.

51. A continuación Ellacuría recoge la exposición de quince formas concretas en que se ha mostrado el poder de la deidad en las religiones, según Zubiri ( $c f r$. RARH, pp. 8284). Véase también PFHR, pp. 45-50. 
que le atribuimos a ella. Y también es así porque la diferenciación de las distintas dimensiones del poder de la deidad proviene de la propia diversidad de lo real (RARH 85).

En este contexto puede afirmarse precisamente que la religación, como actitud radical del hombre, es la actualización del carácter poderoso de lo real en cuanto deidad. Como en cualquier otra actualización del hombre como realidad personal, él pone en función su "actitud radical". Puesto que en cada uno de esos actos se actualiza "la realidad en su carácter de poder y puesto que a través de cada uno de estos actos va configurando la figura de su ser personal, resulta que en cada uno de sus actos el hombre va realizando la experiencia de la deidad". La realidad humana, pues, "es la experiencia misma de la deidad, en su propio ser [de lo] sustantivo del hombre" (RARH 86).

\subsubsection{El hombre y las cosas desde la religación}

\section{(a) Dimensiones de la realidad}

Para responder adecuadamente a la cuarta cuestión sobre cómo aparecen las cosas y el hombre desde la perspectiva de la religación, Ellacuría expone que la deidad no es una propiedad más que tienen las cosas, sino que formalmente las constituye en su "carácter de reales". Por tanto, la deidad no está separada de las cosas reales, sino que se encuentra en el interior mismo de ellas. Y, recíprocamente, puede decirse que sólo en las cosas reales el ser humano "actualiza el carácter de realidad", en cuanto dominante (RARH 87).

Ahora bien, realidad y deidad no se identifican sin más. Esto permite entender y distinguir dos dimensiones de las cosas reales. Efectivamente, en la medida en que ellas son "nuda realidad, constituyen el ámbito de lo profano". Y en la medida en que las cosas son "un momento interno de la deidad" constituyen el ámbito de la religación. Por tanto, la diferencia fundamental no es entre lo sagrado y lo profano, sino entre "lo profano y lo religado" (RARH 87).

Naturalmente, lo religioso puede ser sagrado, pero lo es por ser religioso y no al revés ( $c f r$. RARH 87). Justo por ello, todos los objetos reales tienen esa "dimensión de deidad y no son ajenos a una actitud de descubrimiento de lo religioso" en el sentido de religación (RARH 87-88). Pues bien, toda realidad tiene dos dimensiones: "la profana y la religiosa" (RARH 88).

\section{(b) Unidad de lo profano y lo religioso}

La unificación de ambas dimensiones de la realidad no es nada fácil y constituye un enigma. El enigma se refiere fundamentalmente a la "visión de una cosa en la relucencia de ella, en otra directamente vista. Es una visión especular de la deidad en toda cosa". De lo cual se desprende que la deidad está presente en las cosas de dos formas (RARH 88). 
La primera es la forma "completiva". Gracias a ella las cosas reales son la "sede de la deidad, y, por lo tanto, religan 'atractivamente". La segunda es la forma "defectiva". Aquí las cosas manifiestan el poder de la deidad "defectivamente" y religan al hombre "aversivamente". En este sentido, se trata de las cosas "vedadas, el tabú". Pero veda y tabú son algo sagrado, justo porque la "realidad de estas cosas es la presencia defectiva y aversiva de la deidad". Esto pone de manifiesto que la unificación entre las cosas reales y la deidad es un enigma. El "enigma de en qué medida la realidad en cuanto tal de las cosas funda el poder de la deidad" (RARH 88).

El enigma no consiste en una "oscuridad estática y quiescente, sino dinámica" (RARH 88). Propiamente, el enigma "significa la condición que las cosas tienen en tanto en cuanto incide en ellas el carácter de la realidad como poder, la deidad". "Este carácter de deidad fundamenta la actualización de la realidad personal del hombre como un yo que ha de ir trazando la figura de su propio ser, precisamente por su carácter de último, posibilitante e imponente [impelente]". Por tal razón puede afirmarse que la actitud radical de la realidad humana es la "religación en la que se actualiza la fundamentalidad de su propio ser" (RARH 89).

\section{(c) Deidad y voz de la conciencia}

Ahora bien, la realidad se hace presente en la realidad humana de un modo singular en virtud del cual aparece lo que se entiende por conciencia. En ella se "actualiza religadamente el poder de la deidad". Y se actualiza primaria y radicalmente por medio del dictado de la voz de la conciencia. Ella es la voz de la realidad en la que "transparece" la deidad. "La voz de la conciencia tiene ese carácter de dictado porque brota de la realidad misma como fundamento de la deidad" (RARH 91).

La conciencia consiste en la "resonancia de ese fundamento" que la realidad del hombre, en cuanto realidad, "encuentra agitándose en su propia realidad". En la voz de la conciencia tenemos efectivamente la resonancia de la realidad en forma de deidad, "pero una resonancia que como tal resuena físicamente a ese fundamento que en ella resuena. Esta resonancia es lo que constituye formalmente la voz de la conciencia". Ésta, en efecto, es la "palpitación sonora del fundamento". La resonancia del fundamento consiste "en su mismo dictar imperioso" (RARH 91).

De esta manera, el enigma adquiere el carácter de una "voz". Una voz que "remite constitutivamente al fundamento de la deidad". En la voz de la conciencia tenemos ante todo la "palpitación y el latido del fundamento, que como realidad, en cuanto tal, hace resonar el carácter de ese fundamento en forma de deidad, pero de suerte que este carácter de deidad remite constitutivamente a su fundamento" (RARH 92). 
En consecuencia, la voz de la conciencia tiene un carácter rigurosamente metafísico. Este carácter se "actualiza en forma de resonancia auditiva, en el yo religado en cuanto tal". En la voz de la conciencia lo que en rigor "resuena es la realidad en cuanto tal". La voz de la conciencia "sería la deidad misma en cuanto resuena en nuestra conciencia". Y, por el hecho de ser voz, la deidad nos actualiza "auditivamente y, por lo tanto, nos está remitiendo a aquello de que ella es voz y a aquello que ha de explicar el enigma: el por qué la realidad está fundada y por qué la realidad fundamenta [...] la deidad" (RARH 92).

La voz de la realidad es voz del fundamento de la realidad. Y si es voz de la realidad resulta que "en la voz de la conciencia nos encontramos con que la resonancia de ese fundamento" es la resonancia del "fundamento de la realidad, en cuanto tal" (RARH 93).

Esto hace que el hombre vea incluidas en "dirección al fundamento todas las realidades que le circundan y entre ellas a sí mismo por el hecho mismo de ser realidades". De esta manera queda aprehendida la entera realidad, en "dirección a su fundamento" (RARH 93).

\section{(d) Deidad y vías religiosas}

Respecto a esta cuestión cabe destacar, en primer lugar, que son tres las vías históricas que la humanidad ha emprendido en la búsqueda del fundamento. La primera es la vía del fundamento "múltiple", que conduce al politeísmo. La segunda es la vía de la "inmanencia", que lleva al panteísmo. Finalmente, está la vía de la "transcendencia", que conduce al monoteísmo (RARH 95).

Por cualquiera de esas vías religiosas el hombre llega a un "fundamento, que ha de entenderse como la divinidad". Ciertamente, se llegará en forma distinta, pero en todas ellas hay un momento inevitable, en virtud del cual "en forma distinta y por caracteres distintos" el hombre accederá real y efectivamente a la divinidad (RARH 95).

En segundo lugar, incluso la persona que no desee comenzar esa "marcha en busca del fundamento y se refugie tan sólo en el dictado de la conciencia [...] está, de algún modo, a las puertas de Dios". En esta perspectiva, pueden distinguirse dos estilos de ateísmo. Uno es el ateísmo "al que se llega por negación del hombre, por aniquilación de su riqueza más radical". El otro es el ateísmo "al que se llega por afirmación del hombre, sea por exaltación o sea por resignación". En el interior mismo del hombre radica la posibilidad del ateísmo ya sea en su forma negativa o en su forma afirmativa (RARH 95).

Desde esta perspectiva afirmativa, la persona "no puede dejar de oír el dictado de su conciencia" que, en este caso, se recluye en el "dictar mismo de la conciencia, en el que está palpitando la divinidad, que constituye la raíz de ese dictado". En este caso, pues, el ateísmo es un "acontecimiento de la conciencia, 
en la palpitación de Dios en el espíritu humano" ${ }^{52}$. Por tanto, es un ateísmo que de alguna manera llega a Dios (RARH 96) ${ }^{53}$.

En esto consiste la ingente experiencia de la humanidad buscando a Dios como fundamento de la deidad, a la cual se siente impulsado por la "resonancia que como voz de la conciencia despierta tal deidad en el espíritu humano" (RARH 98).

En conclusión, la gran experiencia histórica que la humanidad ha tenido de Dios es la "expansión del latido constitutivo de la divinidad en el espíritu de la humanidad que se expande y se difunde en ondas distintas, las cuales tienen, sin embargo, un eje vector" (RARH 98-99).

\section{(e) Deidad y revelación}

Ese eje vector se pone de manifiesto con mayor claridad desde una estricta "revelación" ${ }^{4}$. La revelación habría de comprenderse en el contexto del marco presentado de la "palpitación de la divinidad en el espíritu humano". Justo en ese marco recibe esa propia y "gratuita palpitación, ésta se le convierte en iluminante". Y por ser iluminante, pone en marcha la entera mentalidad de la persona que la ha recibido para exteriorizar precisamente lo recibido (RARH 99).

Pero siempre será una iluminación que surge profundamente de la palpitación de Dios, en el seno del espíritu del hombre. A esta "se la llama palabra porque esa iluminación va destinada a los demás, y a los demás se les transmite por palabras". Pero en la persona que recibe la revelación "es una iluminación interior" (RARH 99).

Este es para Ellacuría el "esquema general antropológico donde esta revelación, caso de darse, habría de situarse". No puede hablarse de revelación si antes no se ha comprendido el "fundamento de la deidad y de la realidad entera como un Dios personal y libre" (RARH 99). En la religación se encuentra, por tanto, el fundamento radical porque justo en la ella se manifiesta lo que es el "fundamento de la actualización personal" (RARH 100).

En definitiva, hemos expuesto en esta segunda sección el hombre, realidad religable; el hombre, realidad religada; y la religación como actitud radical del hombre.

52. Sobre el ateísmo, puede verse también I. Ellacuría, "Existencialismo ateo", en DiosAteísmo. Tercera semana de teología. Universidad de Deusto, Bilbao, 1968, pp. 191-212.

53. A continuación Ellacuría expone pormenorizadamente que la cuestión de las vías religiosas que pueden llevar de la deidad a su fundamento no es solo una cuestión lógica, sino asimismo un problema histórico ( $c f r$. RARH, pp. 96-98).

54. Sobre "la revelación en Zubiri", véase también A. Torres Queiruga, Filosofía de la religión en Xavier Zubiri, óp. cit., pp. 85-99. 


\section{Conclusión}

Al llegar a este punto de la exposición merece la pena plasmar algunas conclusiones y unas breves valoraciones que, a nuestro modo de ver, se desprenden del presente trabajo sobre la realidad humana y la religación.

En primer lugar, hemos encontrado en la primera parte de El hombre y Dios de Zubiri, el marco global y maduro para comprender en modo adecuado el significado de la realidad humana y la religación y su íntima relación. Ello posibilitó clarificar lo que se entiende por realidad humana y al mismo tiempo permitió desbrozar la función de la religación en la constitución del hombre.

La realidad humana es un sistema sustantivo de notas gracias a las cuales vive, siente e inteligencia sentientemente. Tales son las notas que conforman el sistema psicosomático del hombre. Es la rigurosa unidad estructural de su sistema psico-orgánico. La sustantividad humana es animal de realidades y, por eso, su formalidad es formalidad de realidad.

Por ser animal de realidades el hombre es "de suyo" pero también es "suyo", es suidad. Ella constituye la razón formal de la personeidad. A las transformaciones concretas que la personeidad adquiere en el transcurso de su vida se le llama personalidad.

El hombre va haciendo su vida personal gracias a sus propias acciones. En virtud de ellas es agente, actor y autor. Ejecutando acciones según esos tres modos es como él realiza su vida personal. En tales acciones el hombre cobra su ser relativamente absoluto. Pero lo cobra apoyado y fundado en "la realidad". Tal apoyo consiste en ser fundamento de la persona (HD 82). Y el fundamento de la realidad es algo último, posibilitante e impelente en la realidad del hombre. La realidad fundamento es el poder de lo real que domina y se apodera del hombre.

Este apoderamiento que acontece ligando al hombre al poder de lo real para ser relativamente absoluto es la religación. Sólo en el hombre ésta es formalmente religación porque sólo en él la religación es el acontecer de la fundamentalidad. La religación no es una teoría, sino un hecho perfectamente constatable en cada uno de los seres humanos. Además, es un hecho total, ya que afecta a todas las dimensiones de la persona. Y también es un hecho radical porque es la raíz que posibilita que cada persona llegue a ser $s u$ Yo. La religación tiene un carácter experiencial en cuanto probación física de realidad; es, además, una manifestación del poder de lo real; y lo manifestado tiene ese carácter enigmático del poder de lo real.

Considero un mérito de Zubiri el haber conceptuado la realidad del hombre como sistema sustantivo de notas cuya formalidad es formalidad de realidad, y al mismo tiempo haber puesto de manifiesto la íntima relación entre realidad humana y religación. En este contexto cabe destacar, ante todo y sobre todo como 
mérito original, su aproximación a la religación partiendo metodológicamente de un "análisis de hechos". Es lo que permite a Zubiri fundar la religión en la religación como plasmación y concreción de la religación en la religión ${ }^{55}$. Por tanto, fundarla en un hecho universal y no en una mera teoría.

Esta conceptuación madura de la realidad humana y su intrínseca relación con la religación es la que precisamente sirve de marco referencial para encuadrar en modo adecuado la recepción de Ellacuría sobre la religación como actitud radical del hombre.

En la segunda parte de nuestro trabajo, Ellacuría mostró lo que es la religación. Esta ha de considerarse como uno de los hallazgos y "logros más personales del Zubiri de la primera época" (RARH 46). En esta perspectiva, puede afirmarse también que la religación es indudablemente el tema "más ligado con el nombre y con la obra" de Zubiri5 ${ }^{56}$.

Desde el primer escrito de Zubiri del año 1935, "En torno al problema de Dios", que Ellacuría presentó en la primera sección de su artículo, vimos que el hombre es realidad religable. El hombre es una realidad personal apoyada en la realidad para hacerse persona. Este apoyo es algo último y radical. Sólo en la realidad humana se actualiza formalmente la religación. Esta es una dimensión constitutiva de la vida humana; en esa dimensión se fundamenta la religión. La religación implanta al hombre en la realidad fundamento que lo fundamenta, y por eso la cuestión del hombre es una cuestión fundamental. De lo cual se desprende que la realidad humana en cuanto realidad es el lugar de la manifestación del fundamento.

En la segunda sección de su exposición, Ellacuría presentó al hombre como realidad religada, siguiendo muy de cerca el artículo de Zubiri, "Introducción al problema de Dios", del año 1963. El hombre ejecuta sus actos sobre cosas concretas, pero los realiza como persona en cuanto persona. Es lo que sitúa al hombre ante la ultimidad, fundante de la actuación personal. La persona se haya apoyada, religada en la ultimidad. La ultimidad es precisamente lo religante. Por tanto, la "religación es la unidad de la persona en cuanto persona humana religada y de la ultimidad en cuanto fundamento y apoyo de la actuación personal del hombre" (RHRH 62).

En la tercera sección de nuestra exposición, titulada "La actitud radical del hombre: religación", Ellacuría parte de dos cursos de Zubiri del año 1965: "El problema filosófico de la historia de las religiones" y "El problema de Dios en la historia de las religiones".

55. En este contexto puede verse J. Corominas, Zubiri y la religión, óp. cit. También A. Torres Queiruga, Filosofía de la religión en Xavier Zubiri, óp. cit.; especialmente, pp. 19-47.

56. A. Torres Queiruga, Filosofía de la religión en Xavier Zubiri, óp. cit., p. 49. 
En ese contexto vimos que el hombre es personeidad. En virtud de su inteligencia él está instalado e implantado en la realidad ejecutando sus actos personales. Pero el hombre también se realiza como tal, por eso en todo acto personal también compromete su "yo". Esta forma y figura de ser que él va cobrando en el ejercicio de sus actos es la personalidad. Es el ser de lo sustantivo de la realidad humana que tiene la misión de irse configurando en medio de la inquietud de la vida. La actitud personal radical del hombre que subyace a todas sus actitudes es la religación, es decir, es esa ligadura del hombre a la realidad en cuanto realidad para que él pueda ser. En ella acontece la fundamentalidad de su ser de lo sustantivo. El fundamento y el apoyo de esta actitud radical es la realidad como algo último, posibilitante e impelente. Lo real según esos tres momentos domina en el hombre. En la religación como actitud radical del hombre se actualiza la fundamentalidad de su propio ser humano.

Considero un mérito original de Ellacuría el haber captado tempranamente (1966) la función primaria de la religación como actitud radical del hombre. Y lo ha hecho partiendo y recogiendo en una sola exposición algunos de los artículos fundamentales de Zubiri de los años 1935, 1963 y 1965. Especial interés merece el escrito de 1935, en el que por vez primera Zubiri aborda la religación. Tales trabajos expresan la comprensión progresiva que Zubiri fue teniendo de la religación. De ahí que la exposición de Ellacuría pueda recuperarse como recepción fiel y adecuada que expresa válidamente una parte fundamental de la evolución histórica de tan radical cuestión en el pensamiento de Zubiri.

A mi juicio, la religación y la realidad humana constituyen una cuestión que tie zne una íntima relación y que sigue cobrando relevancia y actualidad en nuestros días ${ }^{57}$. La actual filosofía del hombre no puede prescindir de la concepción de Zubiri sobre la realidad humana y la religación, a la que Ellacuría dedicó una particular atención.

Esta filosofía antropológica expuesta por Zubiri, y recibida fielmente por Ellacuría, ofrece además algunos elementos que pueden contribuir en modo significativo a replantear creativamente algunas cuestiones de la religión y la teología actuales. El concepto de religación, en efecto, se convierte en la raíz filosófica última, tanto de una posible filosofía de la religión como de una reflexión teológica sobre la revelación ${ }^{58}$. En esta perspectiva, la revelación ha de comprenderse en el marco de la religación ( $c f r$. RARH 99).

57. En esta perspectiva puede verse la reciente obra de D. Ferrer, Razón y religación. Una aproximación radical a la filosofía de Zubiri, Madrid, 2008. También A. Torres Queiruga, Filosofía de la religión en Xavier Zubiri, óp. cit.; concretamente, pp. 49-84.

58. J. L. Cabria Ortega, Relación Teología-Filosofía en el pensamiento de Xavier Zubiri, pp. 66-67. 
Siglas usadas para la obra de X. Zubiri:

EPD "En torno al problema de Dios", en NDH, pp. 417-454.

HD Hombre y Dios, Madrid, $1998^{6}$.

IL Inteligencia y logos, Madrid, 1982.

IRA Inteligencia y razón, Madrid, 1983.

IRE Inteligencia sentiente. Inteligencia y realidad, Madrid, $1991^{4}$.

NHD Naturaleza, Historia, Dios, Madrid, $1999^{11}$.

PFHR El problema filosófico de la historia de las religiones, Madrid, $1994^{2 \text { re }}$.

Sigla usada para la obra de I. Ellacuría:

RARH "La religación, actitud radical del hombre", en Escritos teológicos I, San Salvador, 2000. 